\title{
ARCHIWA I KANCELARIE PARAFIALNE W DEKANCIE KSIĄŻ WIELKI W ŚWIETLE AKT WIZYTACJI Z 1783 ROKU
}

Celem niniejszego artykułu jest przedstawienie zasobów archiwów parafialnych i omówienie działalności kancelarii parafialnych w dekanacie Książ Wielki u schyłku XVIII stulecia. Wspomniana jednostka administracji kościelnej w omawianym okresie położona była w archidiakonacie krakowskim, będącym częścią diecezji krakowskiej. Dekanat Książ Wielki składał się wówczas z 16 parafii: Radziemice, Łętkowice, Nasiechowice, Sławice, Mstyczów, Kozłów, Książ Wielki, Miechów, Kalina, Racławice, Zielenice, Wrocimowice, Pałecznica, Małoszów, Słaboszów, Książ Mały'

Już na wstępie zasygnalizować należy problem natury terminologicznej. Przez pojecie archiwum w czasach przedrozbiorowych rozumiano zbiór wszelkich luźnych dokumentów, ich kopii oraz kopiariuszy. Do biblioteki zaliczano natomiast metryki oraz albumy brackie ${ }^{2}$. Granice między dwoma rodzajami zbiorów kulturalnych jakimi były biblioteki i archiwa kościelne w okresie staropolskim przebiegały zatem nieco inaczej niż obecnie, a tym co je różniło była postać fizyczna obiektu (księga, luźny dokument) czy rodzaj pisma (druk, rękopis) przechowywa-

* Hubert Mazur - mgr historii, archiwista w Instytucie Pamięci Narodowej w Kielcach.

${ }^{1}$ Dekanat Książ Wielki nie doczekał się jak dotąd osobnego opracowania. Nieco informacji na temat historii poszczególnych parafii podał J. Wiśniewski, Dekanat miechowski, Radom 1917. Jedynie dwie parafie stały się przedmiotem oddzielnych monografii: zob. Z. Pęckowski, Miechów. Studia z dziejów miasta i ziemi miechowskiej do 1914 roku, Kraków 1967; E. Madejski, Kościót parafialny św. Wojciecha w Książu Wielkim, Książ Wielki 1999; Zob. też H. Mazur, Biblioteki parafialne w dekanacie Ksiaż Wielki w drugiej połowie XVIII wieku, „Archiwa Biblioteki i Muzea Kościelne” (dalej: ABMK), 88 (2008) s. 111-113.

${ }^{2}$ W. Kowalski, Znaczenie archiwów parafialnych dla badań nad dziejami przedrozbiorowymi, ABMK, 75 (2001), s. 48. 
nych w nich zbiorów ${ }^{3}$. Niemniej jednak w niniejszym artykule pojęcie archiwum używane będzie w jego dzisiejszym rozumieniu ${ }^{4}$.

Podstawęźródłową prezentowanego artykułu stanowią akta wizytacji dekanatu Książ Wielki przeprowadzonej w 1783 r. przez kanonika sandomierskiego ks. Jacka Kochańskiego z polecenia ówczesnego administratora diecezji krakowskiej arcybiskupa Michała Poniatowskiego, przechowywane obecnie w Archiwum Kurii Metropolitalnej w Krakowie. Zawierają one opisy majątku ruchomego i nieruchomego poszczególnych kościołów, w tym inwentarze książek oraz spisy dokumentów. Ogromne znaczenie i wysoka wartość poznawcza akt wizytacji jako źródeł historycznych dowiedziona została już wielokrotnie, w tym przede wszystkim przez Stanisława Litaka ${ }^{5}$, zwalnia to tym samym autora od szerszych rozważań w tej materii.

Skromnie przedstawia się literatura poświęcona archiwom parafialnym. Największe zasługi w tej kwestii oddaje artykuł Waldemara Kowalskiego poświęcony działalności aktotwórczej parafialnych kancelarii, narastaniu zasobów parafialnych archiwów i ich współczesnej dostępności ${ }^{6}$. Istotne znaczenie ma też praca Roberta Kufla ${ }^{7}$, będąca próbę syntetycznego ujęcia problemu. Napisano również nieco artykułów stanowiących omówienie zasobów archiwalnych z konkretnego obszaru czy danej parafii ${ }^{8}$. Ogromne znaczenie dla prezentowanej pracy ma artykuł Marii Dębowskiej i Ryszarda Skrzyniarza traktujący o zachowanej spuściźnie aktowej zakonu bożogrobców w Miechowie9.

Rozwój archiwów i kancelarii parafialnych zarówno w Europie jak i w Polsce wiążę się z uchwałami soboru trydenckiego, które regulowały kwestię ochrony i urządzania archiwów kościelnych oraz nałożyły na duchowieństwo obowiązek rejestracji ludności tzn. prowadzenia ksiąg ochrzczonych i zaślubionych ${ }^{10}$, dotychczas obowiązujący jedynie w niektórych partykularnych ustawodawstwach

${ }^{3}$ S. Librowski, Archiwa, biblioteki i muzea kościelne. Podobieństwa i różnice. Próba rozgraniczenia, ABMK, 16 (1968) s. 5-18.

${ }^{4}$ Nowa Encyklopedia Powszechna PWN, t. 1, Warszawa 1995, s. 212; Polski Stownik Archiwal$n y$, red. W. Maciejewska, Warszawa 1974, s. 19, 20.

${ }^{5}$ S. Litak, Akta wizytacyjne parafii z XVI-XVIII w jako źródło historyczne, „Zeszyty Naukowe KUL", 5 (1962), nr 3, s. 41-58; Tenże, Wstęp, w: Akta wizytacji generalnej diecezji inflanckiej i kurlandzkiej czyli piltyńskiej z 1761 roku, wyd. S. Litak, Toruń 1998.

${ }^{6}$ Kowalski, Znaczenie archiwów, s. 19-63.

${ }^{7}$ R. Kufel, Kancelaria, registratura i archiwum parafialne na ziemiach polskich od XII do poczatku XXI wieku, Zielona Góra 2004.

${ }^{8}$ Przykładowo: R. Skrzyniarz, Archiwum parafialne w Bielinach, ABMK, 75 (2001) s. 251-259; F. Stopniak, Archiwa parafialne dekanatu lubelskiego, ABMK 9 (1964) s. 5-19; J. Szymański, Archiwum i biblioteka parafialna w Wojniczu, ABMK, 2 (1961) s. 167-176; A. Weiss, Archiwa parafialne archidiecezji poznańskiej na przyktadzie Wolsztyna, ABMK 75 (2001) s. 109-122.

${ }^{9}$ M. Dębowska, R. Skrzyniarz, Materiały do dziejów bożogrobców w archiwum parafialnym w Miechowie, ABMK 86 (2006), s. 83-106.

${ }^{10}$ S. K. Olczak, Kancelarie kościelne w okresie staropolskim, ABMK, 64 (1995) s. 22; B. Kumor, Metryki parafialne w archiwach diecezjalnych, „Kwartalnik Historii Kultury Materialnej”, 14 (1966) 1, s. 65-66; H. E. Wyczawski, Przygotowanie do studiów w archiwach kościelnych, Kalwaria Zebrzydowska 1989, s. 278. 
kościelnych w Europie ${ }^{11}$. Echa reform trydenckich silnie odbiły się w polskim ustawodawstwie kościelnym dotyczącym archiwów. Najwcześniej sprawą kancelarii kościelnych zajęto się na synodzie włocławskim bpa Stanisława Karnkowskiego z 1579 r., a następnie na synodzie wileńskim (1582) bpa Jerzego Radziwiłła, gdzie wprowadzono nakaz prowadzenia ksiag metrykalnych ${ }^{12}$. Najdonioślejszym wydarzeniem w recepcji prawa trydenckiego w Polsce był List pasterski kardynała Bernarda Maciejowskiego z 1601 r. do duchowieństwa diecezji krakowskiej ${ }^{13}$. Dokument przypominał duchowieństwu parafialnemu o prowadzeniu ksiag metrykalnych tj. ochrzczonych, bierzmowanych, zawierających związki małżeńskie, spisów osób zaniedbujących obowiązek spowiedzi i komunii świętej wielkanocnej, wykazów dekretów wizytacyjnych, osób ekskomunikowanych, roczników zmarłych oraz spisów wszystkich parafian, które miały być sporządzane przy okazji kolędy. Pastoralna Maciejowskiego została w roku 1607 przyjęta przez Synod piotrkowski, a co za tym idzie oddziaływała na prawodawstwo diecezjalne, które odtąd więcej uwagi poświęcać zaczęło archiwom i kancelariom parafialnym ${ }^{14}$.

Dokumentacja metrykalna, do prowadzenia której zobligowani zostali plebani, służyć miała zdyscyplinowaniu zarówno wiernych jak i samego duchowieństwa oraz walce z reformacją oraz różnymi problemami czy patologiami społecznymi. Mniejsze znaczenie miał natomiast aspekt ekonomiczny ${ }^{15}$.

W diecezji krakowskiej prowadzenie spisów ochrzczonych i zaślubionych nakazał dopiero kardynał Radziwiłł ${ }^{16}$, choć w niektórych parafiach zwyczaj ten przyjął się nieco wcześniej ${ }^{17}$.

Akta wizytacji Poniatowskiego, podobnie jak wszystkie źródła tego typu, informują w zasadzie tylko o praktycznej realizacji postulatów prowadzenia parafialnej rejestracji ludności oraz o aktualnym stanie takich spisów, nie dają natomiast na ogół podstaw do dokładnego określenia początków takiej rejestracji, ani szczegółowego zakresu strat $\mathrm{w}$ każdej z wizytowanych parafii ${ }^{18}$.

Niemniej jednak wiadomo, że przynajmniej w części kościołów dekanatu Książ Wielki spisy takie prowadzono już w początkach XVII w. Prawdopodobnie najwcześniej do rejestracji ochrzczonych i zaślubionych, bo od 1601 r., przystą-

${ }^{11}$ J. Kurpas, Poczatki ksiag metrykalnych, ABMK, 2 (1961) z. 1-2, s. 21-40.

${ }^{12}$ Tamże, s. 66-67.

${ }^{13}$ Zob. szerzej S. Nasiorowski, List pasterski kard. Bernarda Maciejowskiego, Lublin 1992, passim.

${ }^{14}$ W. Abraham, Ustawodawstwo kościelne o archiwach, „Archeion”, 4 (1928) s. 6-7; Weiss, Archiwa parafialne, s. 110.

${ }^{15}$ Szerzej zob. I. Gieysztorowa, Wstęp do demografii staropolskiej, Warszawa 1976, s. 200; Kowalski, Znaczenie archiwów, s. 20-21.

${ }^{16}$ J. Kracik, Przeciw reformacji, w: Kościół krakowski w tysiqcleciu, Kraków 2000, s. 193.

${ }^{17} \mathrm{~Np}$. w Kielcach od 1565 r., zob. Z. Guldon, Księgi metrykalne z XVI-XVII wieku w archiwach diecezjalnych w Kielcach i Sandomierzu, w: Dzieje Kielecczyzny w historiografii Polski Ludowej. Baza Źródłowa, red. Z. Guldon, M. B. Markowski, cz. 1, Kielce 1987, s. 77.

${ }^{18}$ Kowalski, Znaczenie archiwów, s. 22. 
piono w Słaboszowie ${ }^{19}$. W Kalinie zastano Liber baptisatorum prowadzoną od roku $1606^{20}$. W ciagu pierwszych dwóch dekad ochrzczonych spisywano w kolejnych trzech parafiach: w Sławicach i Pałecznicy od 1619 r. i w Książu Wielkim od $1620 \mathrm{r}^{21}$ Zdecydowanie mniej zrozumienia w tym okresie plebani wykazali dla rejestracji ślubów. Księgi takie prowadzono tylko w Słaboszowie (od 1601 r.), Pałecznicy (od 1619 r.) i Sławicach (od 1620 r.) $)^{22}$.

Do początku lat trzydziestych XVII wieku w Polsce nie było obowiązku rejestrowania zgonów ${ }^{23}$. Dopiero w drugiej połowie tegoż stulecia zaczęły upowszechniać się i to dość powoli księgi zmarłych, choć w niektórych parafiach spisywanie zejść zdarzało się już wcześniej np. w Bogorii i Rudawie od 1622 r. ${ }^{24}$, w Koniecpolu od $1623 \mathrm{r} .{ }^{25}$, a także w Bielinach od $1637 \mathrm{r}^{26} \mathrm{O}$ zaprowadzenia Liber mortuorum zadecydował przyjęty w roku 1631 przez wszystkie polskie diecezje $R y$ tuat Piotrkowski ${ }^{27}$. Nie wszędzie przestrzegano jednak jego zaleceń, bowiem w archidiakonacie sandomierskim zmarłych notowano jedynie sporadycznie ${ }^{28}$. W recepcji zwyczaju rejestrowania zmarłych pewną rolę odegrało zapisywanie opłat za pogrzeby. Jednak głównym chyba powodem zakładania tychże ksiąg była próba kontroli wypełniania obowiązku spowiedzi i komunii chorych ${ }^{29}$.

Także w parafiach dekanatu Książ Wielki znacznie później przystąpiono do spisywania zmarłych. Nastapiło to dopiero w drugiej połowie XVII stulecia. W 1783 r. wizytator w Pałecznicy zastał Liber mortuorum prowadzoną od $1652 \mathrm{r}^{30} \mathrm{~W}$ innych parafiach notowanie zmarłych praktykowano od lat sześćdziesiatych (Radziemice, Kozłów, Książ Wielki) ${ }^{31}$, w pozostałych w ciągu ostatnich dziesięcioleci XVII i pierwszych dekad XVIII w.

Przynajmniej od połowy XVIII stulecia we wszystkich parafiach dekanatu Książ Wielki prowadzono już wszystkie rodzaje wyżej wspomnianych ksiąg metrykalnych. Dokładny ich stan w 1783 r. ilustrują zestawienia 1-3.

${ }^{19}$ Archiwum Kurii Metropolitarnej w Krakowie, Acta Visitationis 54 (dalej: AKMKr, AV 54), s. 417.

${ }^{20}$ Tamże, s. 365.

${ }^{21}$ Tamże, s. 267, 315, 404.

${ }^{22}$ Tamże, s. 268, 402.

${ }^{23}$ Kumor, Metryki parafialne, s. 67.

${ }^{24}$ Kowalski, Znaczenie archiwów, s. 53-63.

${ }^{25}$ A. Szczukocki, Motywy śmierci i przemijania w ikonografii ksiag zmartych parafii Koniecpol w latach 1623-1695, Kielce 1995, (praca magisterska napisana pod kier. W. Kowalskiego, której maszynopis znajduje się w Archiwum Uniwersytetu Humanistyczno-Przyrodniczego Jana Kochanowskiego w Kielcach).

${ }^{26}$ Skrzyniarz, Archiwum parafialne, s. 253.

${ }^{27}$ Kumor, Metryki parafialne, s. 67.

${ }^{28}$ Kowalski, Znaczenie archiwów, s. 25.

${ }^{29}$ Tamże, s. 25-27.

${ }^{30}$ AKMKr, AV 54, s. 402.

${ }^{31}$ Tamże, s. 238, 298, 315. 
Księgi metrykalne nie prowadzone były zbyt starannie przez kler parafialny, który dopuszczał się na tym tle wielu zaniedbań, przewinień, czy nadużyćc ${ }^{32}$. Księża często w kwestii sporządzania rejestrów wyręczali się organistami lub nauczycielami, a nawet uczniami szkół parafialnych ${ }^{33}$. Z tymi praktykami próbowali walczyć z różnym skutkiem biskupi ${ }^{34}$. Także na terenie dekanatu Książ Wielki stan metryk nie zawsze zadawalał wizytatora. Wielokrotnie rejestry te spisywano jedynie na luźnych kartach, które potem często ginęły. Tak było min. w Radziemicach, gdzie poza Liber baptisatorum prowadzoną od 1655 r. zastano „dawniejszych porozrzucanych kart kilkanaście”,35 a w Książu Wielkim odnotowano „Metryki [...]

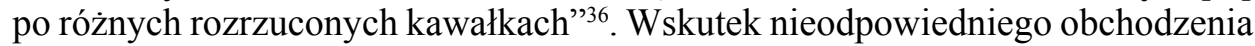
się z metrykaliami często ulegały one podarciu, porozrywaniu i zniszczeniu ${ }^{37}$. Dochodziło także do sytuacji bardziej skrajnych jak np. w Nasiechowicach, gdzie księgi „dawniejsze przez niedbalstwo pogniły”38.

Metrykalia w okresie staropolskim często ulegały zniszczeniu wskutek pożarów trawiących kościoły. Tak było w parafii Łętkowice, gdzie notariusz wizytacyjny zapisał, że księgi prowadzono w niej przed rokiem 1772, spłonęły one jednak wraz z plebanią․

Dodać należy, że niektóre z ksiąg metrykalnych wykazanych przez akta wizytacji Poniatowskiego w parafiach Książ Mały, Książ Wielki, Łętkowice, Miechów, Mstyczów, Nasiechowice, Słaboszów, Sławice i Wrocimowice zachowały się i znajdują się obecnie w zasobie Archiwum Diecezjalnego w Kielcach ${ }^{40}$.

Ustawodawcy diecezjalni obligowali parafialny kler do prowadzenia szeregu innych spisów min. rejestrowania bierzmowanych, dokumentowania zapowiedzi przedślubnych i przystępowania do spowiedzi wielkanocnej ${ }^{41}$. Natomiast coroczna wizyta duszpasterska miała być w zamyśle biskupów okazją do sporządzania spisów wszystkich parafian - libri status animarum ${ }^{42}$. Na ogół większość tych

${ }^{32}$ Kowalski, Znaczenie archiwów, s. 27, 28; Z. Zaborski, Z dziejów parafii Lelów i Staromieście, Częstochowa 1998, s. 285.

${ }^{33}$ Olczak, Kancelarie kościelne, s. 22

${ }^{34}$ Kowalski, Znaczenie archiwów, s. 28-29.

${ }^{35}$ AKMKr, AV 54, s. 238.

${ }^{36}$ Tamże, s. 315.

${ }^{37}$ Przykładowo w Sławicach, AKMKr, AV 54, s. 267: „Wszystkie te książki w złej oprawie, podarte”; zaś we Wrocimowicach, AKMKr AV 54, s. 390: „wszystkich ksiagg sześć i kawałek najstarszej jeden".

${ }^{38}$ AKMKr, AV 54, s. 256.

${ }^{39}$ Tamże, s. 249: "Metryki [...] tylko od roku 1772 znajdują się, ponieważ dawniejsze wraz z plebanią pogorzały".

${ }^{40}$ Archiwum Diecezjalne w Kielcach, Katalog ksiąg metrykalnych. Zob. też Z. Guldon, Księgi metrykalne.

${ }^{41}$ Bp krakowski Marcin Szyszkowski w swych statutach synodalnych zobligował plebanów do prowadzenia 27 rozmaitych spisów i repertoriów, zob. Kumor, Metryki parafialne, s. 155, 156; S. Litak, Struktura i funkcje parafii w Polsce, w: Kościół w Polsce, red. J. Kłoczowski, t. 2, Wieki XVIXVIII, Kraków 1969, s. 449.

${ }^{42}$ B. Kumor, Księgi ,status animarum” $w$ diecezjach polskich (do roku 1918), „Przeszłość Demograficzna Polski” (dalej: PDP), 1 (1967) s. 89-109; Gieysztorowa, Wstęp, s. 123-125. 
postulatów w skali całej diecezji krakowskiej pozostawała martwą literą ${ }^{43}$. Także w aktach wizytacji dekanatu Książ Wielki nie odnotowano jakichkolwiek śladów prowadzenia wspomnianych wyżej rejestrów.

Przedłożone natomiast wizytatorowi przez proboszczów każdej z 16 parafii wchodzących w skład omawianej jednostki administracji kościelnej liczby: wszystkich parafian, przystępujących do komunii wielkanocnej, ochrzczonych, zaślubionych, zmarłych, a także innowiercó ${ }^{44}$ pozostawały zapewne w związku z nakazem wydanym w 1766 r. przez bpa Kajetana Ignacego Sołtyka, który zobowiązywał plebanów do gromadzenia wyżej wymienionych danych ${ }^{45}$.

$\mathrm{W}$ parafiach znajdowała się też dokumentacja wytworzona przez rozmaite instytucje religijne, społeczne i charytatywne. Do takich należały bractwa. Najczęściej w wyniku ich działalności powstawały wykazy należących do ich struktury braci i sióstr. Były to tzw. księgi brackie albo albumy brackie ${ }^{46}$. W 1783 wizytator zastał je jedynie w Radziemicach, Kalinie, Wrocimowicach, Pałecznicy i Książu Małym ${ }^{47}$.

Zarządzeniem biskupa Kajetana Ignacego Sołtyka z 1781 r., a następnie prymasa Poniatowskiego z 1783 r. proboszczowie zobligowani zostali do prowadzenia sumariuszy praw i dokumentów, w których zawarte miały być w porządku chronologicznym wszystkie dokumenty uposażeniowe i majątkowe kościoła ${ }^{48}$. Tworzyły je min. dziesiątki odpisów z akt urzędów kościelnych jak i świeckich, akta prowadzonych spraw sądowych, ekstrakty z Liber beneficiorum i Liber retaxationum. Z protokołów wizytacyjnych wynika, że duchowieństwo skrupulatnie wypełniło wspomniany nakaz, sumariusze takie zastano bowiem w $1783 \mathrm{r}$. w czternastu parafiach całego dekanatu ${ }^{49}$. Brak sumariuszy odnotowano jedynie w Miechowi $^{50}$. W Nasiechowicach pleban przedłożył wizytatorowi dokumenty w bar-

${ }^{43}$ Kowalski, Znaczenie archiwów, s. 20-23.

${ }^{44}$ AKMKr, AV 54, s. 233, 245, 252, 253, 265, 274, 294, 306, 340, 361, 370, 377, 386, 397, 406, $412,425$.

${ }^{45}$ Kowalski, Znaczenie archiwów, s. 30; B. Kumor, Nieznane źródła do statystyki diecezji krakowskiej w XVIII w., PDP, 4 (1971), s. 23.

46 Tamże, s. 44-45; S. Litak, Bractwa religijne w Polsce przedrozbiorowej XIII-XVIII wiek. Rozwój i problematyka, „Przegląd Historyczny”, 88 (1997) z. 3-4, s. 499-523.

${ }^{47}$ W Radziemicach, AKMKr, AV 54, s. 329: „książka S. Józefa”; w Kalinie, AKMKr, AV 54, s.365: „księga bracka do wpisywania jedna”; we Wrocimowicach, AKMKr, AV 54, s 390: „książka do wpisywania braci i sióstr S. Scapularis”; w Pałecznicy, AKMKr, AV 54, s. 402: „książka do wpisywania bractwa”, W Książu Małym, AKMKr, AV 54, s. 429: „księga bracka do wpisywania jedna".

${ }^{48}$ Kowalski, Znaczenie archiwów, s. 40-41.

${ }^{49}$ AKMKr, AV 54, s. 239-240, 249-250, 268-270, 279, 299, 315-316, 365-366, 372, 381, 390 391, 402-403, 409, 417-418, 430-432.

${ }^{50}$ Tamże, s. 353: „Sumariusz praw i dokumentów dla przedłożonych i za sprawiedliwe uznanych przyczyn nie jest teraz podany do akt wizyty teraźniejszej, uskutecznienie do przyszłej [wizyty] jest odłożone". 
dzo skromnej liczbie, gdyż większość z nich znajdowała się w mającej prawo patronatu nad nasiechowicką farą Akademii Krakowskiej ${ }^{51}$.

Osobne sumariusze prowadzone były dla przykościelnych prebend, bractw, scholasterii, promotorii, a także dla miechowskiego szpitala ${ }^{52}$.

Kler parafialny zobligowany był też do posiadania dokumentów jurysdykcyjnych, przede wszystkim świadectw uprawniających do głoszenia kazań i zdolności do słuchania spowiedzi ${ }^{53}$. W aktach wizytacji dekanatu Książ Wielki posiadanie tych dokumentów lub ich brak skrupulatnie odnotowywano ${ }^{54}$. W znakomitej większości parafii plebani okazywali żądane od nich świadectwa ${ }^{55}$.

Innym rodzajem parafialnej dokumentacji, o której sporadycznie informuja akta wizytacji Poniatowskiego były spisy dochodów i obligacji mszalnych ${ }^{56}$. Prowadzenie takich rejestrów odnotowano w Radziemicach, Racławicach, Zielenicach, Pałecznicy i Książu Wielkim ${ }^{57}$.

W okresie XVIII stulecia tylko nieliczne kościoły posiadały oryginalne dokumenty z czasów średniowiecza ${ }^{58}$. Wizytacja dekanatu ksiąskiego nie wykazała tego typu archiwaliów w żadnej z wizytowanych świątyń. Prawdopodobnie jednak takie dokumenty w niektórych parafiach mogły zostać pominięte przez wizytacyjnych notariuszy. Tak stało się np. w Miechowie. Tam bowiem do chwili obecnej znajduje się księga zawierająca kopie dokumentów z lat 1198-1602 zwana kopiarzem miechowskim (Liber privilegiorum ad bona conventus Miechoviensis). W archiwum parafialnym w Miechowie przechowywane są także archiwalia z okresu przedrozbiorowego, niewzmiankowane przez wizytację Poniatowskiego min.: osiemnastowieczne klasztorne kroniki, akta wizytacji 28 placówek filial-

${ }^{51}$ AKMKr, AV 54, s. 257: „Sumariusz praw i dokumentów kościoła nasiechowickiego nie jest tu położony dostatecznie, nastały albowiem dopiero przed rokiem JM ksiądz pleban żadnych dokumentów przy kościele nie zastał. Te mają być złożone w Archiwum Akademii jako mającej prawo kolacji”.

${ }^{52}$ Tamże, s. 284, 286, 288, 324, 327, 356, 358, 418.

${ }^{53} \mathrm{~F}$. Lenort, Rodzime elementy normatywne i rozwój dokumentu kościelnego w Polsce przedrozbiorowej, „Poznańskie Studia Teologiczne”, 2 (1978) s. 254-272; Tenże, Libri inscriptionum paroeciales w okresie staropolskim. Aspekt normatywny, w: Ecclesia Posnanensis. Opuscula Mariano Banaszak septuagenario dedicata, red. F. Lenort i K. Lutyński, Poznań 1998, s. 100-101.

${ }^{54}$ AKMKr, AV 54, s. 243, 252, 263, 273, 289, 305, 329, 354-355, 368, 375, 385, 396, 405, 411, $423,435$.

${ }^{55}$ Przykładowo w Sławicach, AKMKr, AV 54, s. 273: ,[ksiądz pleban] aprobowany do słuchania spowiedzi w konsystorzu generalnym krakowskim na rok dnia 16 kwietnia 1783 roku. Rekolekcje odprawił w kościele miechowskim według zaświadczenia dnia 10 kwietnia roku 1783"; jedynie w Kozłowie, AKMKr, AV 54, s. 305: pleban ,aprobacji do słuchania spowiedzi i odprawianych rekolekcji zaświadczenia nie okazał".

${ }^{56}$ Kowalski, Znaczenie archiwów, s. 42.

${ }^{57}$ AKMKr, AV 54, s. 234, 308, 370, 378, 399. Przykładowo (AKMKr, AV 54, s. 308): „W Książu Wielkim obligacyi oprócz parafialnych zwyczajnych i anniwersarza jednego za czynsz od sumy dwóch tysięcy złotych na wsi Korabnikach zapisanej innych nie masz".

${ }^{58}$ Kowalski, Znaczenie archiwów, s. 34. 
nych klasztoru miechowskiego (1524-1774), inwentarze, księgi brackie z XVII i XVIII w. oraz księgi metrykalne ${ }^{59}$.

Brak w aktach wizytacji Poniatowskiego jakichkolwiek danych o wygotowywaniu dokumentów przez kancelarie parafialne na terenie dekanatu ksiąskiego. $\mathrm{O}$ tej formie działalności proboszczów świadczyć mogą pojawiające się w inwentarzach niektórych kościołów pieczęcie ${ }^{60}$. Prawdopodobnie jednak ich pierwszoplanowym zastosowaniem było pieczętowanie pism adresowanych do parafii przez władze diecezjalne ${ }^{61}$.

Kończąc analizę zasobów parafialnych dekanatu Książ Wielki przypomnieć raz jeszcze wypada, że przez cały okres przedrozbiorowy księgi metrykalne i brackie stale traktowane były jako cześć biblioteki, a pojęcie archiwum odnoszono do dokumentów, ich luźnych kopii oraz sumariuszy. Identyczna sytuacja miała miejsce w dekanacie Książ Wielki.

Podstawowy zasób parafialnych archiwów na terenie przedrozbiorowego dekanatu ksiąskiego stanowiły księgi metrykalne. Spisy ochrzczonych i zaślubionych najwcześniej zaczęto prowadzić w Słaboszowie od 1601 r. Należy przyjać, że rejestracja ta upowszechniła się w ciagu XVII stulecia. Zaś w drugiej połowie XVIII w. ochrzczonych i zaślubionych spisywano już we wszystkich parafiach. Zdecydowanie później zaprowadzono Libri mortuorum. W Pałecznicy zgony rejestrowano już od 1652 r., w pozostałych parafiach na ogół spisy takie powstawały od początku wieku XVIII. Poza metrykami w niektórych archiwach (a raczej bibliotekach) farnych znajdowały się albumy brackie. O zasobie dokumentowym kościołów informują sumariusze praw i dokumentów, zawierające głównie wyciaggi z Liber beneficiorum i Liber retaxationum, odpisy z urzędów i sądów kościelnych i świeckich. W protokołach wizytacyjnych odnotowywano wreszcie świadectwa uprawniające kler do głoszenia kazań i słuchania spowiedzi. Wykazany zrąb zasobów archiwów parafialnych dekanatu Książ Wielki, nie odbiegał od stanu jaki reprezentowały inne polskie archiwa parafialne w tym okresie.

\footnotetext{
${ }^{59}$ Szerzej zob. Dębowska, Skrzyniarz, Materiały do dziejów, s. 92-105; Pęckowski, Miechów, s. 431-433.

${ }^{60}$ Nasiechowice, gdzie „pieczęć kościelna mosiężna jedna” i Miechów, gdzie „pieczęć duża żelazna", a nadto Sławice i Mstyczów; AKMKr, AV 54, s. 255, 266, 277, 344.

${ }^{61}$ Lenort, Rodzime elementy, s. 251, 270-272.
} 


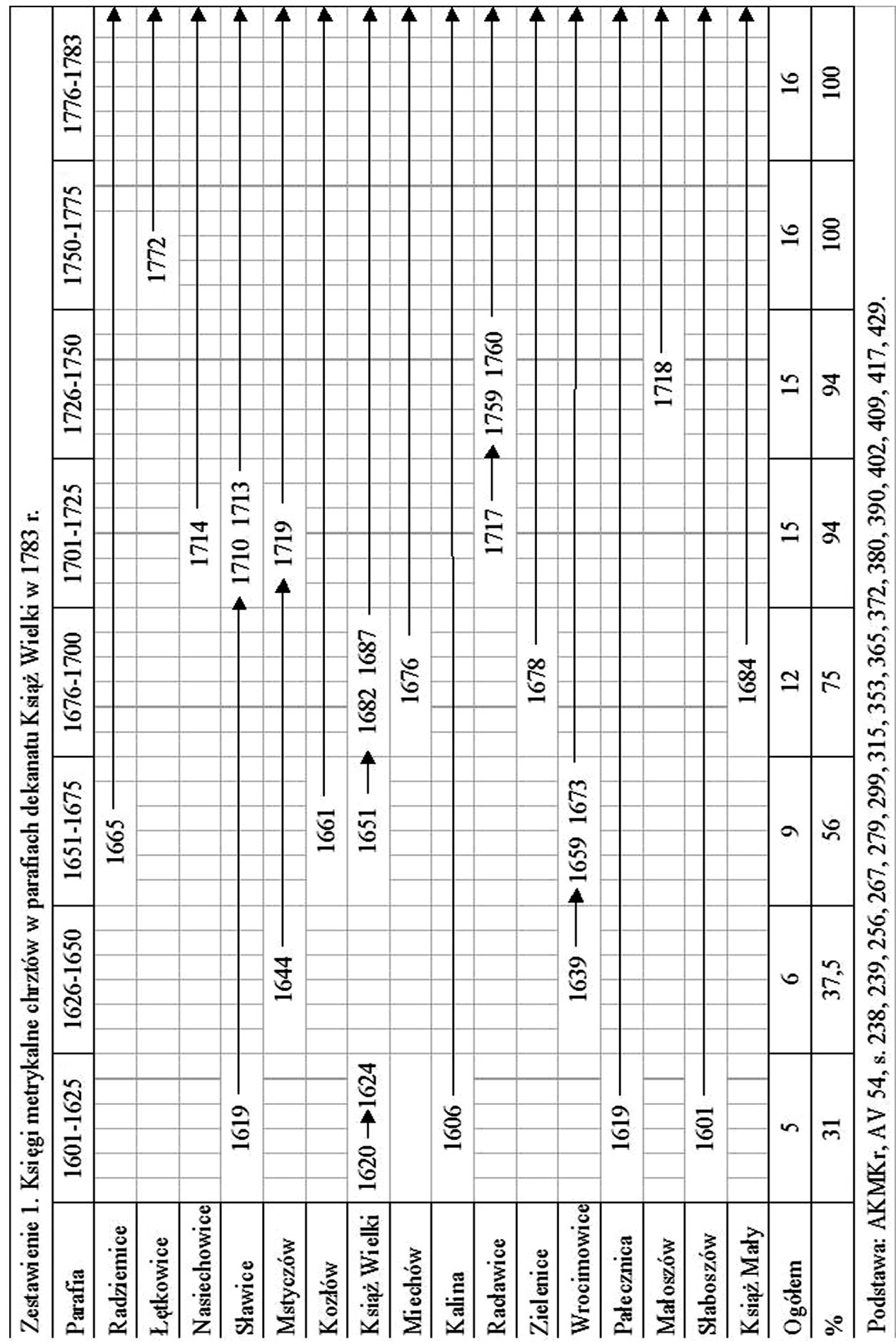




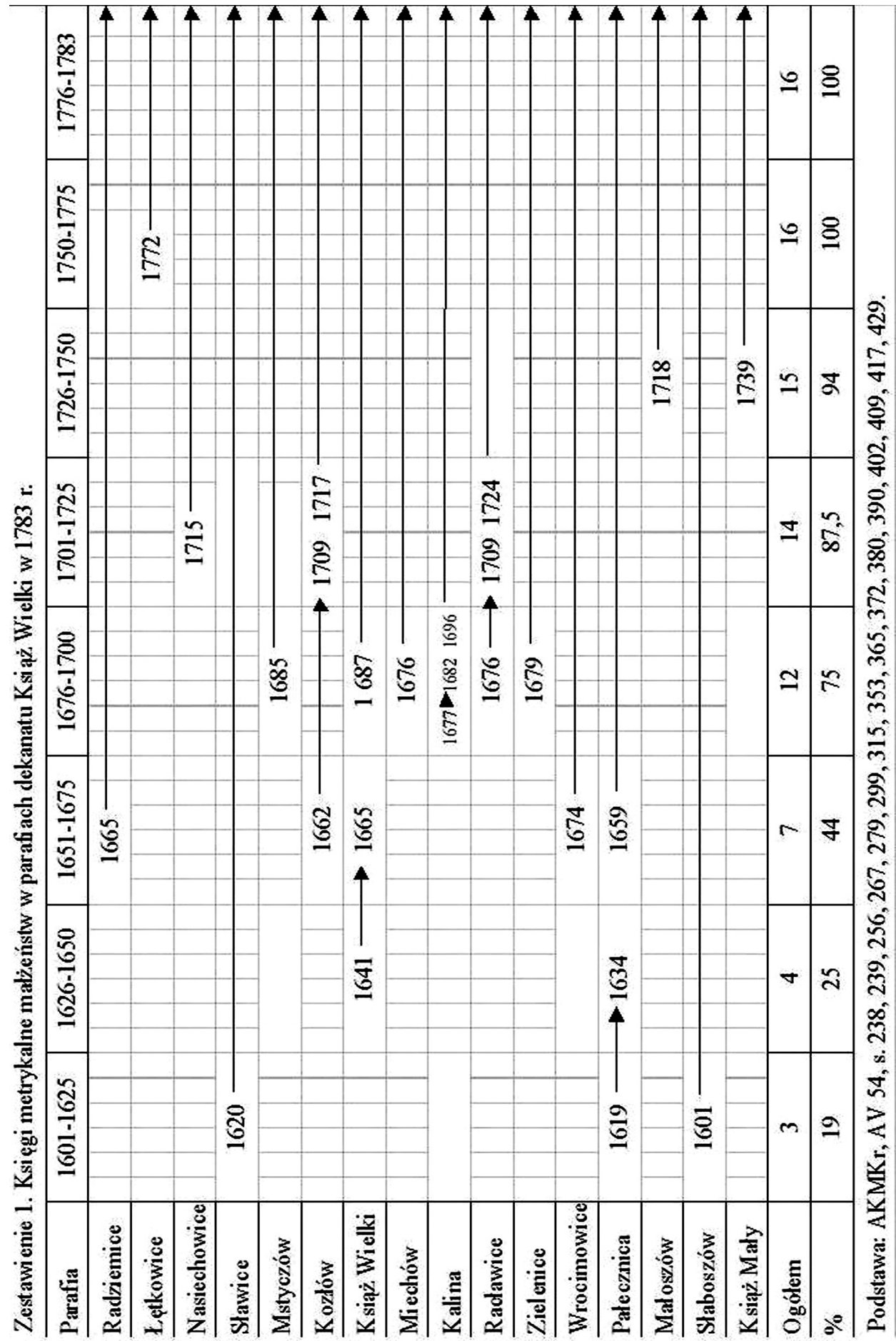




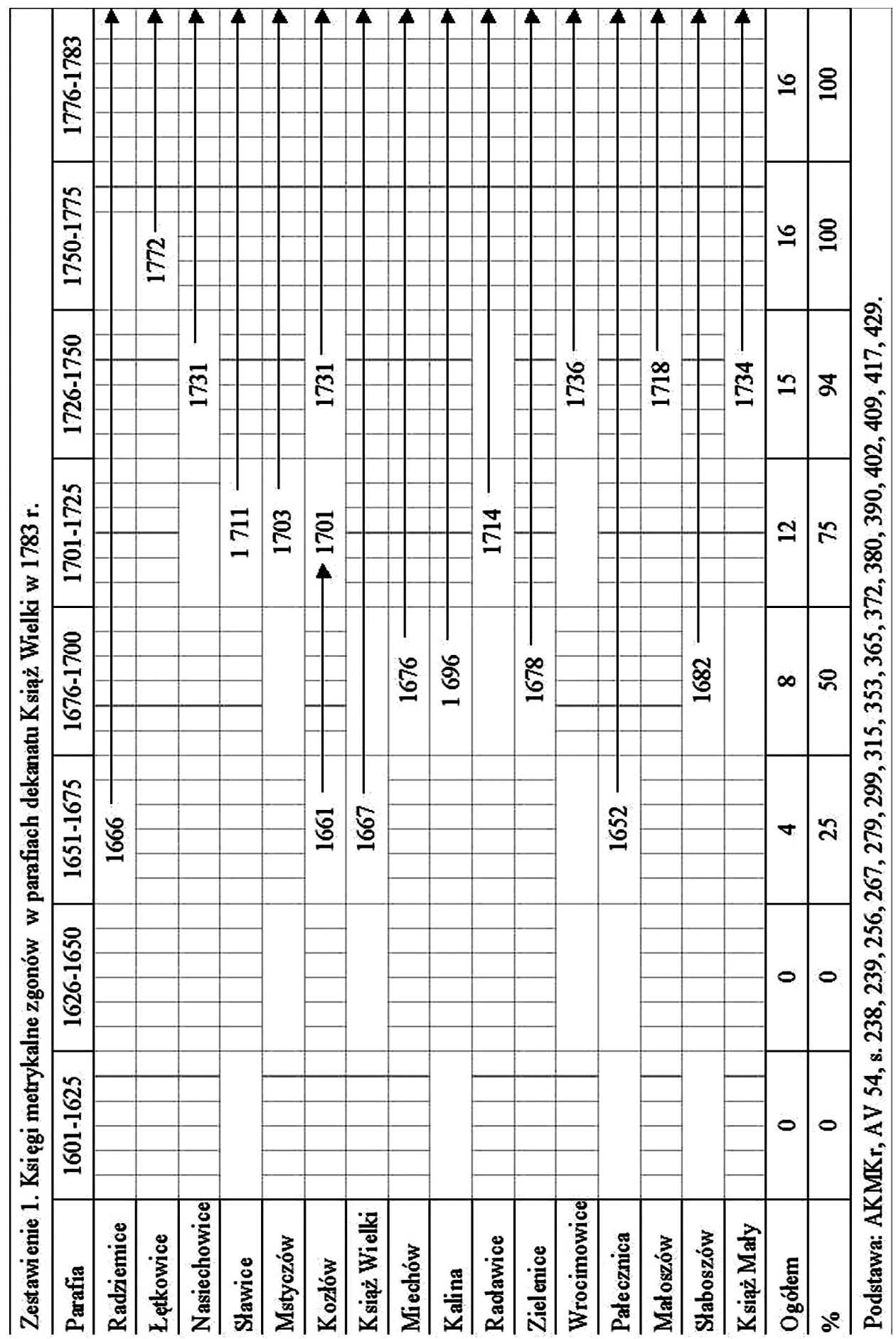




\section{DIE PFARRARCHIVE UND PFARRKANZLEIEN IM DEKANAT KSIĄŻ WIELKI IM LICHTE DER VISITATIONSAKTEN VON 1783}

\section{Zusammenfassung}

Der vorliegende Artikel bildet den Versuch einer Besprechung der Bestände der Pfarrarchive und der Tätigkeit der Pfarrkanzleien auf dem Gebiet des Dekanats Książ Wielki im ausgehenden 18. Jahrhundert. Den Betrachtungen des Verfassers liegen die Akten der 1783 in 16 Pfarreien dieses Dekanats durchgeführten bischöflichen Visitation zugrunde. Die Grundlage der Pfarrarchive im Dekanat Książ Wielki von 1783 bildeten die Kirchenmatrikel. Am frühesten, denn bereits in den ersten Jahrzehnten des 17. Jahrhunderts, begann man mit dem Führen von Taufregistern (Słaboszów, Kalina Sławice, Pałecznica und Książ Wielki). Etwas langsamer und säumiger verlief die Rezeption des Brauchs, auch Heiratsbücher zu führen. Obligatorische Sterbebücher wurden in Polen erst 1631 durch das „Petrikauer Rituale” eingeführt. In einem Teil der Pfarreien des Dekanats Książ Wielki (Pałecznica, Radziemice, Kozłów, Książ Wielki) begann man in der zweiten Hälfte des 17. Jahrhunderts mit dem Führen von Sterbebüchern, in den übrigen Pfarreien erst im Laufe der letzten Jahrzehnte des 17. und der ersten Jahrzehnte des 18. Jahrhunderts. In einigen Pfarrarchiven des Dekanats Książ Wielki (Radziemice, Wrocimowice, Pałecznica und Książ Mały) befanden sich auch zu den Bruderschaften gehörende Verzeichnisse, die sogenannten Fraternitätsalben oder Bruderschaftsbücher. Über die Aktenbestände der einzelnen Kirchen informierten die auf Verfügung von Bischof Sołtyk und Primas Poniatowski eingeführten „Summarien der Rechte und Dokumente”, die alle Dokumente über die Bezüge und Besitztümer der jeweiligen Kirche enthalten sollten. Solche „Summarien” gab es 1783 in 14 Pfarreien des gesamten Dekanats, was davon zeugt, dass dies allgemein so gehandhabt wurde. In den Visitationsakten von Książ Wielki aus dem Jahre 1783 wurde auch festgehalten, welche zum Halten von Predigten und zum Hören der Beichte berechtigende Zeugnisse die Geistlichen besaßen, seltener auch das Vorhandensein von Verzeichnissen und Messstipendien. Poniatowskis Visitationsakten verzeichneten dagegen in keiner der 16 Pfarreien des Dekanats Książ Wielki Originaldokumente aus der Zeit des Mittelalters, keine Register der Gefirmten, der Eheankündigungen und der Teilnehmer an der Osterbeichte und auch keine Verzeichnisse aller Mitglieder der Pfarrgemeinde. Von der außerordentlich bescheidenen aktenschöpferischen Tätigkeit der Pfarrherren kann das Vorhandensein von Stempeln in einigten Pfarreien zeugen. Es muss betont werden, dass man in der Zeit vor den Polnischen Teilungen unter dem Begriff des Archivs eine Sammlung von losen Dokumenten, Kopien von Dokumenten und Kopienbüchern verstand. Dagegen wurden die Matrikelbücher und Fraternitätsalben zur Bibliothek gezählt. 